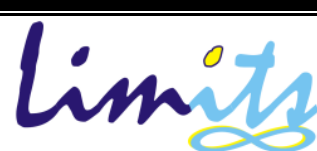

Limits: Journal of Mathematics and Its Applications

E-ISSN: 2579-8936

P-ISSN: 1829-605X

Vol. 17, No. 2, Desember 2020, 139-156

DOI: http://dx.doi.org/10.12962/limits.v17i2.6692

\title{
Kontrol Penyebaran Penyakit SARS dengan Menggunakan Analisis Sensitivitas pada Bilangan Reproduksi Dasar
}

\author{
Benny Yong ${ }^{1 *}$, Putri Efelin ${ }^{2}$ \\ ${ }^{1,2}$ Universitas Katolik Parahyangan, Jl. Ciumbuleuit 94 Bandung 40141 \\ ${ }^{1,2}$ Departemen Matematika UNPAR Bandung Indonesia \\ *e-mail: benny_y@unpar.ac.id
}

Diajukan:9 Maret 2020, Diperbaiki: 7 Oktober 2020, Diterima:28 Oktober 2020

\begin{abstract}
Abstrak
Makalah ini membahas analisis sensitivitas pada bilangan reproduksi dasar pada model penyebaran penyakit SARS dengan pengaruh vaksinasi. Model melibatkan individu rentan, individu terinfeksi tapi belum dapat menularkan, individu yang diisolasi, individu terinfeksi yang dapat menularkan dan belum terdiagnosa SARS, individu pulih, dan individu meninggal karena penyakit $S A R S$, dan individu rentan yang telah divaksin. Karena ketidakpastian dalam penaksiran nilai parameter yang mengakibatkan bervariasinya nilai bilangan reproduksi dasar, akan dilakukan simulasi Monte Carlo pada bilangan reproduksi dasar dengan menggunakan berbagai distribusi untuk setiap parameternya. Hasil analisis sensitivitas pada model penyebaran penyakit SARS dengan pengaruh vaksinasi menunjukkan bahwa parameter proporsi individu isolasi yang berpotensi menginfeksi individu rentan mempunyai pengaruh positif terbesar dalam penyebaran penyakit SARS untuk semua kondisi nilai bilangan reproduksi dasar. Parameter proporsi individu rentan yang berhasil divaksin sebelum terjadinya SARS dalam suatu populasi mempunyai pengaruh negatif terbesar dalam penyebaran penyakit SARS ketika kondisi bilangan reproduksi dasar bernilai kurang dari satu, sedangkan parameter laju pemulihan dari individu isolasi mempunyai pengaruh negatif terbesar dalam penyebaran penyakit SARS untuk kondisi bilangan reproduksi dasar bernilai lebih dari satu.
\end{abstract}

Kata Kunci: SARS, bilangan reproduksi dasar, simulasi Monte Carlo, analisis sensitivitas.

\begin{abstract}
This paper discusses sensitivity analysis of basic reproductive number of SARS epidemic model with vaccination. Model in the form of a compartmental model including susceptible, latent, isolated, infectious, recovered, dead, vaccinated individuals. Because uncertainty in estimating the value of parameters, Monte Carlo simulation is used here to estimate the variability of basic reproductive number using different distributions of the parameters. Effectiveness of isolation is the most positive sensitive parameter in the basic reproductive number for all conditions. Proportion of susceptible successfully vaccinated is the most negative sensitive parameter when value of basic reproductive number less than one, whereas recovery rate of diagnosed individuals is the most negative sensitive parameter if basic reproductive number greater than one.
\end{abstract}

Keywords: SARS, basic reproductive number, Monte Carlo simulation, sensitivity analysis. 


\section{Pendahuluan}

Salah satu penyakit menular yang sempat terjadi di dunia ini adalah Severe Acute Respiratory Syndrome (SARS). SARS adalah suatu jenis penyakit pernapasan yang disebabkan oleh SARS Coronavirus (SARS-Cov) dan biasanya akan berpotensi menimbulkan penyakit radang paru-paru yang fatal. Pada tahun 2004, peneliti di Tiongkok akhirnya menemukan vaksin SARS

Beberapa penelitian telah membahas tentang pemodelan matematika untuk penyakit SARS. Pada makalahnya, Y. Zhou dan Z. Ma pada 2003 memodelkan penyebaran dan kontrol penyakit SARS di Cina dengan menggunakan model epidemik diskret. Pada makalah lain, J. Zhang, J. Lou, Z. Ma, dan J. Wu pada 2004 menganalisis pola penyebaran penyakit SARS di Cina melalui sebuah model matematika. W. Wang dan S. Ruan pada 2004 mengkonstruksi sebuah model matematika untuk melakukan simulasi penyebaran SARS di Beijing. Sedangkan G. Chowell, dkk. pada 2015 membandingkan pola dan dinamika penyebaran dari MERS dan SARS.

Pada makalah [3] telah dibahas mengenai model matematika untuk penyakit SARS dengan dua kondisi yaitu model pre-outbreak vaccination (POV) dan model during-outbreak vaccination ( $D O V$ ). Pada model POV, vaksin diberikan sebelum terjadinya wabah SARS dalam sebuah populasi sedangkan pada model $D O V$, vaksin diberikan selama terdapat penyakit $S A R S$ di dalam populasi itu. Hasil simulasi numerik pada [2] menunjukkan bahwa lebih baik menerapkan model $P O V$ daripada model $D O V$ karena durasi waktu dimulainya vaksinasi setelah terjadinya wabah penyakit $S A R S$ dalam suatu populasi tidak memiliki pengaruh yang besar terhadap jumlah kasus penyebaran penyakit SARS secara kumulatif.

Pada makalah ini bilangan reproduksi dasar dari kedua model tersebut akan ditaksir melalui simulasi Monte Carlo. Hal tersebut dilakukan karena bilangan reproduksi dasar yang bervariasi akibat ketidakpastian dalam penaksiran nilai parameter [17]. Karena model $P O V$ merupakan model yang paling baik untuk mengontrol penyebaran penyakit SARS, maka pada makalah ini akan dianalisis parameter mana yang paling berpengaruh dalam mengontrol penyebaran penyakit $S A R S$ melalui analisis sensitivitas pada model $P O V$ saja.

Batasan masalah yang digunakan dalam makalah ini adalah jumlah populasi konstan, individu yang sudah pulih tidak dapat kembali menjadi individu yang rentan terhadap penyakit, individu isolasi masih dapat menginfeksi individu rentan, penyakit ini hanya untuk populasi manusia, dan vaksin hanya untuk individu rentan. 


\section{Proses Pemodelan}

Model $P O V$ melibatkan individu rentan $(S)$, individu terinfeksi tapi belum bisa menularkan (individu laten) yang akan dibagi menjadi dua yaitu individu yang belum terdiagnosa $S A R S\left(E_{n}\right)$ dan individu yang sudah terdiagnosa $\operatorname{SARS}\left(E_{i}\right)$, individu yang diisolasi $(W)$, individu terinfeksi yang sudah bisa menularkan dan belum terdiagnosa $S A R S(I)$, individu pulih $(R)$, serta individu meninggal karena penyakit SARS $(D)$ dengan $N$ adalah total populasi. Pada model ini, sebanyak $\sigma N$ individu divaksin terlebih dahulu sebelum terjadinya wabah SARS dengan $\sigma$ adalah proporsi individu yang berhasil divaksin sebelum terjadinya wabah SARS. Hal tersebut menyebabkan banyaknya individu rentan awalnya adalah sebanyak $(1-\sigma) N$. Diagram kompartemen model POV disajikan pada Gambar 1 dengan nilai parameternya diberikan pada Tabel 1.

Tabel 1. Definisi Parameter [2]

\begin{tabular}{clc}
\hline Parameter & \multicolumn{1}{c}{ Definisi } & Nilai [3] \\
\hline$\beta$ & Laju transmisi & 0,25 \\
$\frac{1}{k}$ & Rata-rata waktu individu laten $\left(E_{n}\right.$ dan $\left.E_{i}\right)$ akan terinfeksi & 6,37 \\
$\gamma_{1}$ & atau diisolasi & 0,0352 \\
$\gamma_{2}$ & Laju pemulihan dari individu terinfeksi & 0,0425 \\
$\alpha$ & Laju pemulihan dari individu isolasi & 0,206 \\
$\delta$ & Laju individu terinfeksi menjadi terdiagnosa dan diisolasi & 0,0279 \\
$\sigma$ & Laju kematian karena terinfeksi $S A R S$ & {$[0,1]$} \\
$\rho$ & Proporsi individu rentan yang berhasil divaksin sebelum & {$[0,1]$} \\
$\theta$ & terjadi wabah $S A R S$ & {$[0,1]$} \\
$l$ & Proporsi individu rentan menjadi individu $E_{i}$ & {$[0,1]$} \\
$\varepsilon$ & Proporsi individu $E_{n}$ yang mengisolasikan dirinya sendiri & {$[0.5,0.9]$} \\
$\chi$ & Proporsi individu isolasi yang berpotensi menginfeksi & {$[0.2,0.5]$} \\
\hline
\end{tabular}

Perubahan jumlah individu rentan terjadi karena adanya kontak dengan individu terinfeksi dan individu yang diisolasi sebanyak $\frac{I+l W}{N} S$ dengan laju transmisi sebesar $\beta$ dan proporsi perpindahan individu rentan ke populasi individu $E_{i}$ sebesar $\rho$. Sehingga jumlah individu rentan yang sukses terinfeksi dan berpindah ke populasi individu $E_{i}$ ada sebanyak $\beta \rho \frac{I+l W}{N} S$. Sedangkan jumlah individu rentan yang sukses terinfeksi dan berpindah ke populasi individu $E_{n}$ ada sebanyak $\beta(1-\rho) \frac{I+l W}{N} S$. Adanya individu $E_{i}$ yang diisolasi dengan laju $k$ akan menyebabkan jumlah individu di $E_{i}$ akan berkurang sebanyak $k E_{i}$. Terjadinya perpindahan individu $E_{n}$ akibat mengisolasikan dirinya sendiri dengan laju sebesar $k$ dan proporsi $\theta$ akan menyebabkan jumlah individu $E_{n}$ berkurang sebanyak $k \theta E_{n}$ dan sisanya sebanyak $k(1-\theta) E_{n}$ akan berpindah ke 
populasi $I$. Jumlah individu terinfeksi akan berkurang karena terjadi perpindahan individu terinfeksi ke populasi individu yang diisolasi sebanyak $\alpha I$, terjadi kematian karena penyakit $S A R S$ sebanyak $\delta I$, dan terjadi pemulihan pada individu terinfeksi sebanyak $\gamma_{1} I$. Sedangkan jumlah individu yang diisolasi akan berkurang karena terjadi pemulihan sebanyak $\gamma_{2} W$ dan akibat adanya kematian karena penyakit $S A R S$ sebanyak $\delta W$.

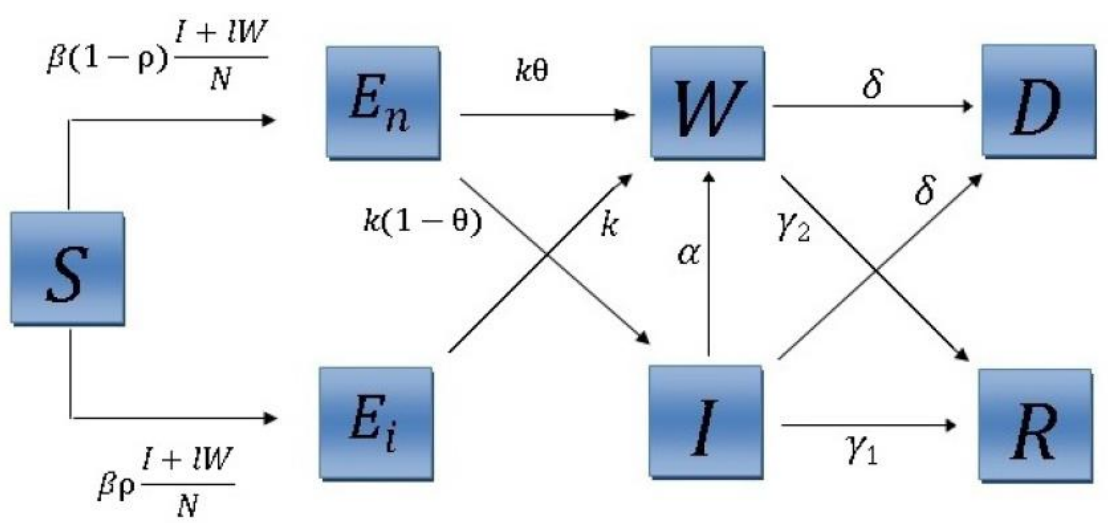

Gambar 1. Diagram kompartemen model $P O V$

Model $P O V$ secara keseluruhan diberikan oleh sistem persamaan (1) sebagai berikut:

$$
\begin{gathered}
\frac{d S}{d t}=-\beta(1-\rho) \frac{(I+l W)}{N} S-\beta \rho \frac{(I+l W)}{N} S \\
\frac{d E_{n}}{d t}=-k \theta E_{n}-k(1-\theta) E_{n}+\beta(1-\rho) \frac{(I+l W)}{N} S \\
\frac{d E_{i}}{d t}=-k E_{i}+\beta \rho \frac{(I+l W)}{N} S \\
\frac{d W}{d t}=k \theta E_{n}+k E_{i}+\alpha I-\left(\delta+\gamma_{2}\right) W \\
\frac{d I}{d t}=k(1-\theta) E_{n}-\left(\alpha+\delta+\gamma_{1}\right) I \\
\frac{d R}{d t}=\gamma_{1} I+\gamma_{2} W \\
\frac{d D}{d t}=\delta I+\delta W
\end{gathered}
$$

Pada model $D O V$, vaksinasi dilakukan selama terjadinya wabah SARS dalam suatu populasi. Pada model ini juga terdapat populasi individu baru yaitu populasi individu rentan yang telah divaksin $(V)$. Individu-individu rentan tersebut divaksin karena melakukan kontak dengan individu yang diisolasi. Diagram kompartemen model DOV disajikan pada Gambar 2. 


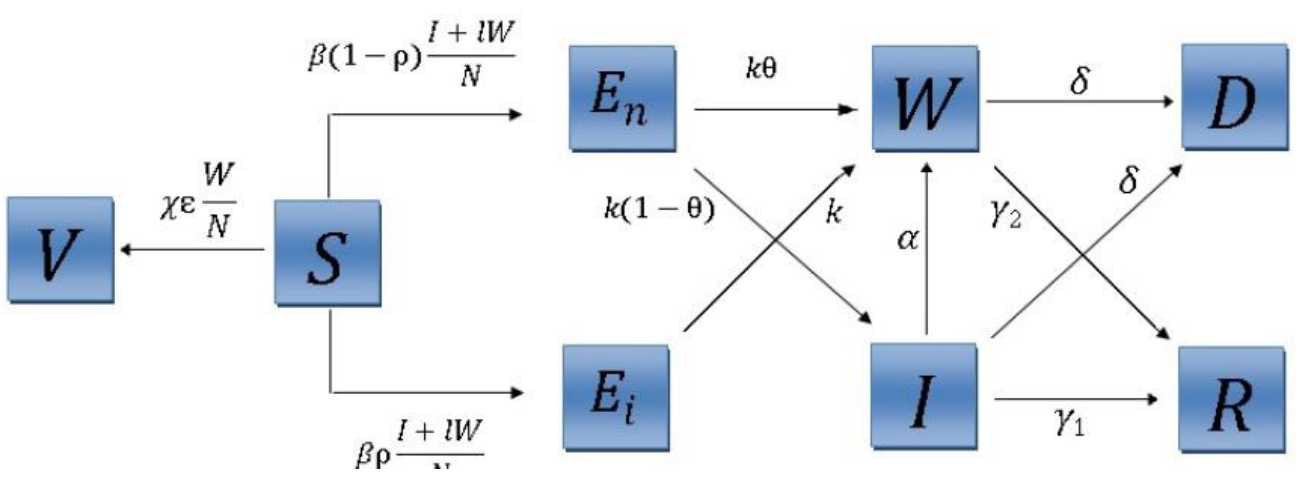

Gambar 2. Diagram kompartemen model $D O V$

Jadi, pada model $D O V$ hanya menambahkan populasi $V$. Persamaan (2) merupakan sistem persamaan dari model $D O V$, yaitu

$$
\begin{gathered}
\frac{d S}{d t}=-\beta(1-\rho) \frac{(I+l W)}{N} S-\beta \rho \frac{(I+l W)}{N} S \\
\frac{d E_{n}}{d t}=-k \theta E_{n}-k(1-\theta) E_{n}+\beta(1-\rho) \frac{(I+l W)}{N} S \\
\frac{d E_{i}}{d t}=-k E_{i}+\beta \rho \frac{(I+l W)}{N} S \\
\frac{d W}{d t}=k \theta E_{n}+k E_{i}+\alpha I-\left(\delta+\gamma_{2}\right) W \\
\frac{d I}{d t}=k(1-\theta) E_{n}-\left(\alpha+\delta+\gamma_{1}\right) I \\
\frac{d R}{d t}=\gamma_{1} I+\gamma_{2} W \\
\frac{d D}{d t}=\delta I+\delta W \\
\frac{d V}{d t}=\chi \varepsilon \frac{W}{N} S
\end{gathered}
$$

Selanjutnya, untuk kedua model ini akan ditentukan ambang batas penyebaran penyakit yang bisa didapat dengan menggunakan matriks generasi. Ambang batas ini biasa dikenal sebagai bilangan reproduksi dasar. Bilangan reproduksi dasar merupakan angka rata-rata kemunculan penularan baru yang disebabkan oleh seorang individu terinfeksi dalam suatu populasi yang semuanya rentan untuk tertular. $[1,4]$.

Titik kesetimbangan bebas penyakit untuk model POV pada sistem (1) adalah

$$
E_{01}\left(S^{*}, E_{n}{ }^{*}, E_{i}{ }^{*}, W^{*}, I^{*}, R^{*}, D^{*}\right)=((1-\sigma) N, 0,0,0,0,0,0)
$$


Untuk model $P O V$, populasi terbagi menjadi 7 kompartemen, misalkan

$$
x=\left(E_{n}, E_{i}, W, I, S, R, D\right)^{T}
$$

dengan

$$
x_{i}(t)=\left(E_{n}, E_{i}, W, I\right)^{T}, i=1,2,3,4
$$

merupakan kompartemen-kompartemen untuk individu terinfeksi. Laju perubahan kompartemen terinfeksi ke- $i$ terhadap waktu adalah

$$
\frac{d x_{i}}{d t}=j_{i}(x)-v_{i}(x)
$$

dengan

$$
j(x)=\left(\begin{array}{c}
\beta(1-\rho) \frac{(I+l W)}{N} S \\
\beta \rho \frac{(I+l W)}{N} S \\
0 \\
0 \\
0 \\
0 \\
0
\end{array}\right), v(x)=\left(\begin{array}{c}
k E_{n} \\
k E_{i} \\
-k \theta E_{n}-k E_{i}+\left(\delta+\gamma_{2}\right) W-\alpha I \\
-k(1-\theta) E_{n}+\left(\alpha+\delta+\gamma_{1}\right) I \\
0 \\
0 \\
0
\end{array}\right)
$$

Diperoleh matriks generasi $[16,18]$

$$
F V^{-1}=\left.\left(\begin{array}{llll}
a & c & e & g \\
b & d & f & h \\
0 & 0 & 0 & 0 \\
0 & 0 & 0 & 0
\end{array}\right)\right|_{E_{01}}
$$

dengan

$$
\begin{gathered}
a=\frac{\beta(1-\rho) l(1-\sigma)\left(\theta\left(\delta+\gamma_{1}\right)\right)+\alpha}{\left(\delta+\gamma_{2}\right)\left(\alpha+\delta+\gamma_{1}\right)}+\frac{\beta(1-\rho)(1-\sigma)(1-\theta)}{\alpha+\delta+\gamma_{1}} \\
b=\frac{\beta \rho l(1-\sigma)\left(\left(\theta\left(\delta+\gamma_{1}\right)\right)+\alpha\right)}{\left(\delta+\gamma_{2}\right)\left(\alpha+\delta+\gamma_{1}\right)}+\frac{\beta \rho(1-\sigma)(1-\theta)}{\alpha+\delta+\gamma_{1}} \\
c=\frac{\beta(1-\rho)(1-\sigma) l}{\delta+\gamma_{2}} \\
d=\frac{\beta \rho l(1-\sigma)}{\delta+\gamma_{2}} \\
e=\frac{\beta(1-\rho) l(1-\sigma)}{\delta+\gamma_{2}} \\
f=\frac{\beta \rho l(1-\sigma)}{\delta+\gamma_{2}} \\
g=\frac{\beta(1-\rho) l(1-\sigma) \alpha}{\left(\delta+\gamma_{2}\right)\left(\alpha+\delta+\gamma_{1}\right)}+\frac{\beta(1-\rho)(1-\sigma)}{\alpha+\delta+\gamma_{1}}
\end{gathered}
$$




$$
h=\frac{\beta \rho l(1-\sigma) \alpha}{\left(\delta+\gamma_{2}\right)\left(\alpha+\delta+\gamma_{1}\right)}+\frac{\beta \rho(1-\sigma)}{\alpha+\delta+\gamma_{1}}
$$

Nilai eigen terbesar dari matriks generasi tersebut merupakan bilangan reproduksi dasar untuk model $P O V$, yaitu:

$$
\mathfrak{R}_{0}=\beta(1-\sigma)\left(\frac{(1-\rho) l \theta}{\delta+\gamma_{2}}+\frac{(1-\rho) l(1-\theta) \alpha}{\left(\delta+\gamma_{2}\right)\left(\alpha+\delta+\gamma_{1}\right)}+\frac{(1-\rho)(1-\theta)}{\left(\alpha+\delta+\gamma_{1}\right)}+\frac{\rho l}{\delta+\gamma_{2}}\right)
$$

Berdasarkan $\mathfrak{R}_{0}$ pada model $P O V$, dapat dilihat bahwa $\beta(1-\sigma)$ menunjukkan berkurangnya laju transmisi akibat vaksinasi sebelum terjadinya wabah $S A R S$ dalam suatu populasi. Laju individu yang belum terdiagnosa SARS terinfeksi akibat melakukan kontak dengan individu isolasi dan kemudian mengisolasikan dirinya sendiri ditunjukkan oleh $\frac{(1-\rho) l \theta}{\delta+\gamma_{2}}$, laju individu yang belum terdiganosa SARS terinfeksi akibat melakukan kontak dengan individu isolasi dan kemudian dapat menularkan infeksi serta terdiagnosa $S A R S$ ditunjukkan oleh $\frac{(1-\rho) l(1-\theta) \alpha}{\left(\delta+\gamma_{2}\right)\left(\alpha+\delta+\gamma_{1}\right)}$, laju individu yang belum terdiagnosa SARS menjadi individu terinfeksi dan dapat menularkan infeksi ke individu rentan ditunjukkan oleh $\frac{(1-\rho)(1-\theta)}{\left(\alpha+\delta+\gamma_{1}\right)}$, sedangkan laju individu rentan yang terinfeksi karena melakukan kontak dengan individu isolasi kemudian menjadi individu yang terdiagnosa SARS ditunjukkan oleh $\frac{\rho l}{\delta+\gamma_{2}}$.

Titik kesetimbangan bebas penyakit untuk model $D O V$ pada sistem (2) adalah:

$$
E_{02}\left(V^{\prime}, S^{\prime}, E_{n}{ }^{\prime}, E_{i}{ }^{\prime}, W^{\prime}, I^{\prime}, R^{\prime}, D^{\prime}\right)=(0, N, 0,0,0,0,0,0)
$$

Untuk model $D O V$, populasi terbagi menjadi 8 kompartemen, misalkan

$$
x=\left(E_{n}, E_{i}, W, I, V, S, R, D\right)^{T}
$$

dengan

$$
x_{i}(t)=\left(E_{n}, E_{i}, W, I\right)^{T}, i=1,2,3,4
$$

merupakan kompartemen-kompartemen untuk individu terinfeksi. Laju perubahan kompartemen terinfeksi ke- $i$ terhadap waktu adalah

$$
\frac{d x_{i}}{d t}=j_{i}(x)-v_{i}(x)
$$


dengan

$$
j(x)=\left(\begin{array}{c}
\beta(1-\rho) \frac{(I+l W)}{N} S \\
\beta \rho \frac{(I+l W)}{N} S \\
0 \\
0 \\
0 \\
0 \\
0 \\
0
\end{array}\right), v(x)=\left(\begin{array}{c}
k E_{n} \\
k E_{i} \\
-k \theta E_{n}-k E_{i}+\left(\delta+\gamma_{2}\right) W-\alpha I \\
-k(1-\theta) E_{n}+\left(\alpha+\delta+\gamma_{1}\right) I \\
0 \\
0 \\
0 \\
0
\end{array}\right)
$$

Diperoleh matriks generasi $[16,18]$

$$
F V^{-1}=\left.\left(\begin{array}{llll}
a & c & e & g \\
b & d & f & h \\
0 & 0 & 0 & 0 \\
0 & 0 & 0 & 0
\end{array}\right)\right|_{E_{02}}
$$

dengan

$$
\begin{gathered}
a=\frac{\beta(1-\rho) l\left(\theta\left(\delta+\gamma_{1}\right)\right)+\alpha}{\left(\delta+\gamma_{2}\right)\left(\alpha+\delta+\gamma_{1}\right)}+\frac{\beta(1-\rho)(1-\theta)}{\alpha+\delta+\gamma_{1}} \\
b=\frac{\beta \rho l\left(\left(\theta\left(\delta+\gamma_{1}\right)\right)+\alpha\right)}{\left(\delta+\gamma_{2}\right)\left(\alpha+\delta+\gamma_{1}\right)}+\frac{\beta \rho(1-\theta)}{\alpha+\delta+\gamma_{1}} \\
c=\frac{\beta(1-\rho) l}{\delta+\gamma_{2}} \\
d=\frac{\beta \rho l}{\delta+\gamma_{2}} \\
e=\frac{\beta(1-\rho) l}{\delta+\gamma_{2}} \\
f=\frac{\beta \rho l}{\delta+\gamma_{2}} \\
g=\frac{\beta(1-\rho) l \alpha}{\left(\delta+\gamma_{2}\right)\left(\alpha+\delta+\gamma_{1}\right)}+\frac{\beta(1-\rho)}{\alpha+\delta+\gamma_{1}} \\
h=\frac{\beta \rho}{\left(\delta+\gamma_{2}\right)\left(\alpha+\delta+\gamma_{1}\right)}+\frac{\beta+\delta+\gamma_{1}}{\alpha+\delta}
\end{gathered}
$$

Nilai eigen terbesar dari matriks generasi tersebut merupakan bilangan reproduksi dasar untuk model $D O V$, yaitu:

$$
\mathfrak{R}_{0}=\beta\left(\frac{(1-\rho) l \theta}{\delta+\gamma_{2}}+\frac{(1-\rho) l(1-\theta) \alpha}{\left(\delta+\gamma_{2}\right)\left(\alpha+\delta+\gamma_{1}\right)}+\frac{(1-\rho)(1-\theta)}{\left(\alpha+\delta+\gamma_{1}\right)}+\frac{\rho l}{\delta+\gamma_{2}}\right)
$$

Berdasarkan $\Re_{0}$ pada model $D O V$, dapat dilihat bahwa $\beta$ menunjukkan laju transmisi ketika terjadinya wabah SARS dalam suatu populasi. Sisanya, semua suku di dalam kurung dari 
bilangan reproduksi dasar pada model $D O V$ ini mempunyai arti yang sama dengan semua suku di dalam kurung dari bilangan reproduksi dasar pada model POV.

Pengambilan suatu data dapat dilakukan dengan cara sampling. Sampling dilakukan jika sebagian saja anggota populasi yang menjadi sampel observasi dan hasilnya merupakan data perkiraan. Metode sampling lebih banyak digunakan karena tetap dapat mengambil kesimpulan tentang keadaan populasi hanya dengan menggunakan sebagian sampel. Teknik penarikan sampel tersebut bisa dilakukan secara acak sederhana atau bisa disebut sampling acak sederhana. Sampling acak sederhana dilakukan jika suatu sampel dipilih dari suatu populasi sehingga setiap kemungkinan sampel mempunyai kesempatan yang sama untuk terpilih [5]. Salah satu cara pengambilan sampel dapat menggunakan simulasi Monte Carlo. Simulasi Monte Carlo menggunakan prinsip hukum bilangan besar. Untuk melakukan simulasi ini, pertama-tama perlu ditentukan suatu interval bilangan acak dari setiap parameter yang digunakan. Kedua, bangkitkan bilangan acak sebanyak yang diperlukan. Selanjutnya, lakukan simulasi dari bilangan-bilangan acak tersebut. Terakhir, cari rata-rata dari hasil simulasi tersebut.

\section{Hasil dan Pembahasan}

Pada bagian ini, akan ditinjau bilangan reproduksi dasar model $P O V$ dan $D O V$ melalui simulasi Monte Carlo. Diketahui distribusi dari setiap parameter yang digunakan sebagai berikut $[3,8,9]$ :

1. Proporsi individu rentan berhasil divaksin $(\sigma) \sim \operatorname{unif}(0,1)$

2. Proporsi individu rentan menjadi terinfeksi tapi belum bisa menularkan $(\rho) \sim \operatorname{unif}(0,1)$

3. Proporsi individu untraced latent yang diisolasi $(\theta) \sim$ unif $(0,1)$

4. Rata-rata waktu individu terinfeksi menjadi terdiagnosa dan diisolasi $\left(\frac{1}{\alpha}\right) \sim \operatorname{Gamma}(\mathrm{a}=1,9$ $; b=2,5)$

5. Rata-rata waktu kematian karena terinfeksi $\operatorname{SARS}\left(\frac{1}{\delta}\right) \sim \operatorname{Gamma}(\mathrm{a}=2,25 ; \mathrm{b}=16)$

6. Rata-rata waktu pemulihan dari individu terinfeksi yang diisolasi $\left(\frac{1}{\gamma_{2}}\right) \sim \operatorname{Gamma}(\mathrm{a}=8,9 ; \mathrm{b}=2,6)$

7. Rata-rata waktu pemulihan dari individu terinfeksi $\left(\frac{1}{\gamma_{2}}\right) \sim \operatorname{Gamma}(\mathrm{a}=8,9 ; \mathrm{b}=2,6)$

8. Laju transmisi perhari $(\beta) \sim \exp (\mu=0,25)$ 
Sedangkan untuk proporsi individu isolasi yang dapat menginfeksi individu rentan $(l)$, dibagi menjadi 4 distribusi,yaitu [3, 8]:

- $1 \sim \operatorname{unif}(0,1)$

- $1 \sim \operatorname{Beta}(\mathrm{a}=2, \mathrm{~b}=2)$

- $1 \sim \operatorname{Beta}(\mathrm{a}=1, \mathrm{~b}=2)$

- $1 \sim \operatorname{Beta}(\mathrm{a}=2, \mathrm{~b}=1)$

Dengan menggunakan program MATLAB, jika nilai parameter-parameter tersebut dibangkitkan sebanyak 100000 kali, hasil satu kali simulasi akan didapat :

Tabel 2. Simulasi $\mathfrak{R}_{0}$ untuk model $P O V$ dan $D O V$

\begin{tabular}{lccrc}
\hline \multirow{2}{*}{ Distribusi dari $\boldsymbol{l}$} & \multicolumn{2}{c}{ Rata-rata $\mathfrak{R}_{\mathbf{0}}$} & \multicolumn{2}{c}{$\boldsymbol{R}_{\mathbf{0}}<\mathbf{1}$} \\
\cline { 2 - 5 } & Model POV & Model $\boldsymbol{D O V}$ & Model $\boldsymbol{P O V}$ & Model $\boldsymbol{D O} \boldsymbol{V}$ \\
\hline$l \sim \operatorname{unif}(0,1)$ & 0,83 & 1,66 & $75 \%$ & $54,05 \%$ \\
$l \sim \operatorname{Beta}(\mathrm{a}=2, \mathrm{~b}=2)$ & 0,83 & 1,66 & $75 \%$ & $51,87 \%$ \\
$l \sim \operatorname{Beta}(\mathrm{a}=1, \mathrm{~b}=2)$ & 0,58 & 1,18 & $83 \%$ & $64,8 \%$ \\
$l \sim \operatorname{Beta}(\mathrm{a}=2, \mathrm{~b}=1)$ & 1,07 & 2,143 & $68 \%$ & $43,28 \%$ \\
\hline
\end{tabular}

Didapat histogram dari keempat distribusi $l$ untuk model $P O V$ sebagai berikut:
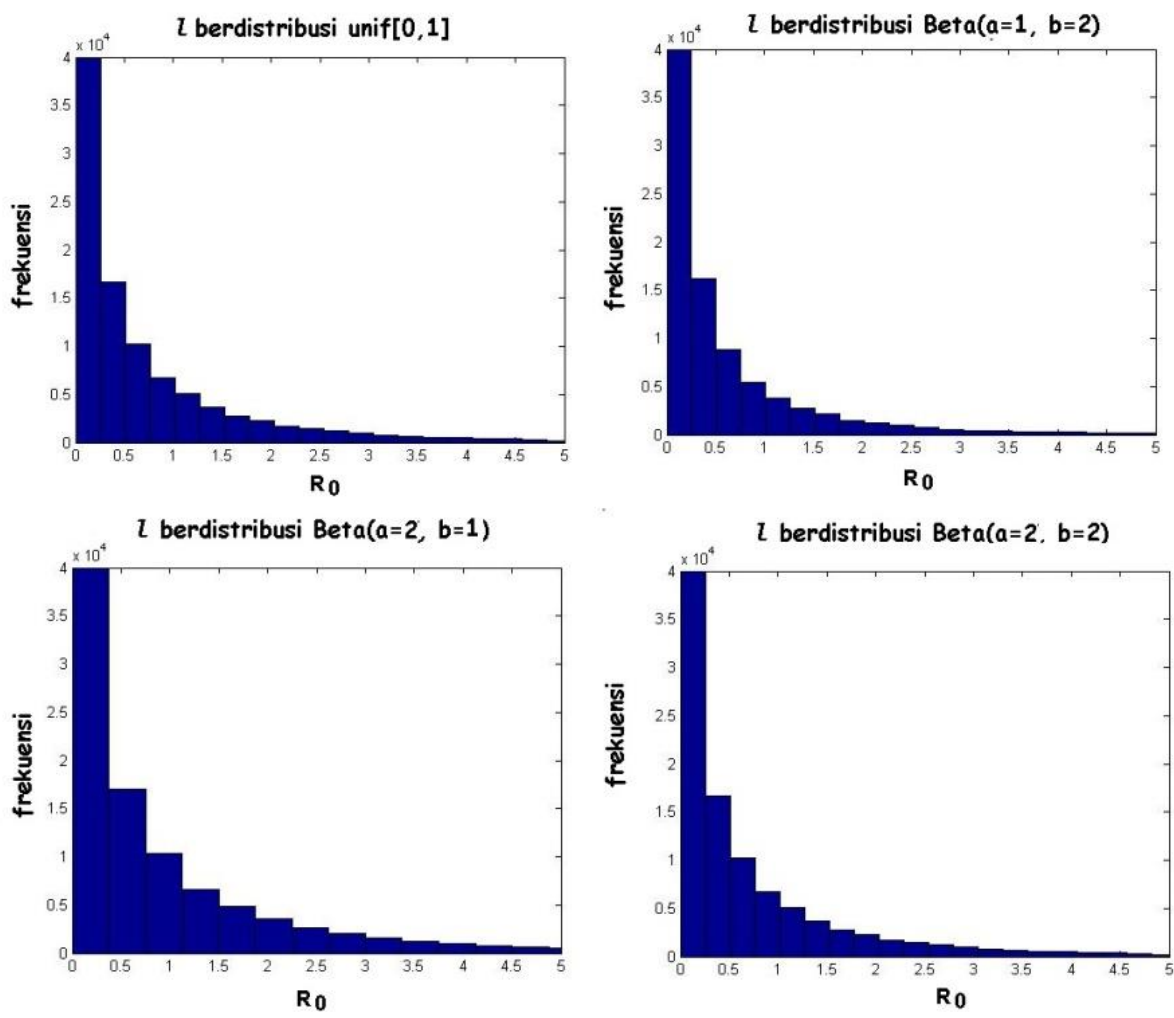

Gambar 3. Histogram dari keempat distribusi $l$ untuk model $P O V$ 
Sedangkan histogram dari keempat distribusi $l$ untuk model $D O V$ sebagai berikut:
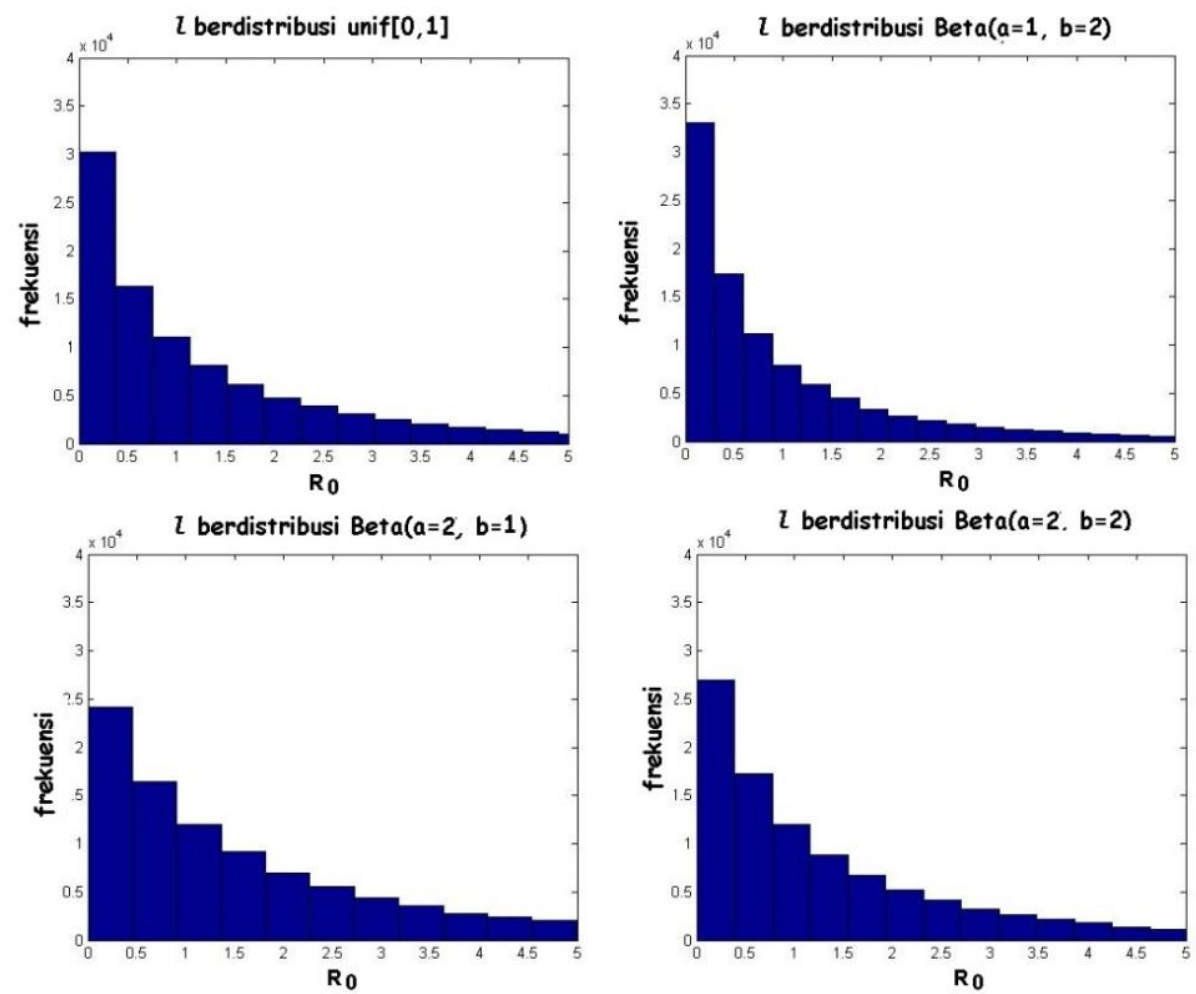

Gambar 4. Histogram dari keempat distribusi $l$ untuk model $D O V$

Berdasarkan Tabel 2, Gambar 3, dan Gambar 4, distribusi dari parameter $l$ yang memiliki pengaruh paling besar pada $\mathfrak{R}_{0}$ baik untuk model $P O V$ dan $D O V$ adalah saat parameter $l$ berdistribusi $\operatorname{Beta}(\mathrm{a}=1, \mathrm{~b}=2)$. Hal ini dikarenakan saat parameter $l$ berdistribusi $\operatorname{Beta}(\mathrm{a}=1, \mathrm{~b}=2)$ memiliki nilai $\mathfrak{R}_{0}<1$ paling besar dan rata-rata $\mathfrak{R}_{0}$ paling kecil.

Berdasarkan paper [2], model $P O V$ lebih baik daripada model $D O V$. Oleh karena itu, akan dilakukan analisis sensitivitas untuk model POV saja. Untuk mengetahui parameter mana yang paling berpengaruh dalam mengontrol penyebaran penyakit $S A R S$, perlu dilakukan analisis sensitivitas pada bilangan reproduksi dasar $\left(\mathfrak{R}_{0}\right)$ untuk setiap parameter yang digunakan $[12,15]$. Analisis sensitivitas pada bilangan reproduksi dasar ini dilakukan hanya untuk model POV karena model tersebut adalah model yang lebih baik dalam mengontrol penyebaran penyakit SARS. Terdapat 8 parameter pada model $P O V$ yang akan diwakili oleh $\lambda$. Didefinisikan sensitivitas untuk $\lambda$ sebagai berikut $[13,14,15]$ :

$$
S_{\lambda}=\frac{\lambda}{\Re_{0}} \cdot \frac{\partial \Re_{0}}{\partial \lambda}
$$

Nilai-nilai parameter akan ditentukan agar menghasilkan $\mathfrak{R}_{0}<1$ dan $\mathfrak{R}_{0}>1$. Parameterparameter yang digunakan berdasarkan data pada Tabel 1 dan berdasarkan simulasi numerik model $P O V$ dan $D O V$. Parameter $l$ dan $\sigma$ diduga sebagai parameter yang dapat mengontrol 
penyebaran penyakit $S A R S$ paling signifikan ketika $\mathfrak{R}_{0}<1$ dan $\mathfrak{R}_{0}>1$. Analisis penyebaran penyakit dilakukan terhadap kondisi bebas penyakit untuk melihat parameter mana yang berpengaruh, terutama terhadap naiknya bilangan reproduksi dasar ketika kondisi ini sehingga pemangku kebijakan dapat mengantisipasi perubahan kondisi dari bebas penyakit menjadi endemik pada suatu wilayah dengan cara melakukan kontrol parameter melalui suatu kebijakan sehingga keadaan wilayahnya tetap bebas dari penyakit. Sedangkan analisis penyebaran penyakit dilakukan terhadap kondisi endemik suatu wilayah agar pemangku kebijakan mendapatkan gambaran untuk melakukan tindakan yang tepat sasaran untuk segera menurunkan bilangan reproduksi dasar ini sehingga wilayahnya menjadi bebas penyakit. Nilai dari kedua parameter $l$ dan $\sigma$ tersebut dipilih berdasarkan Gambar 5.

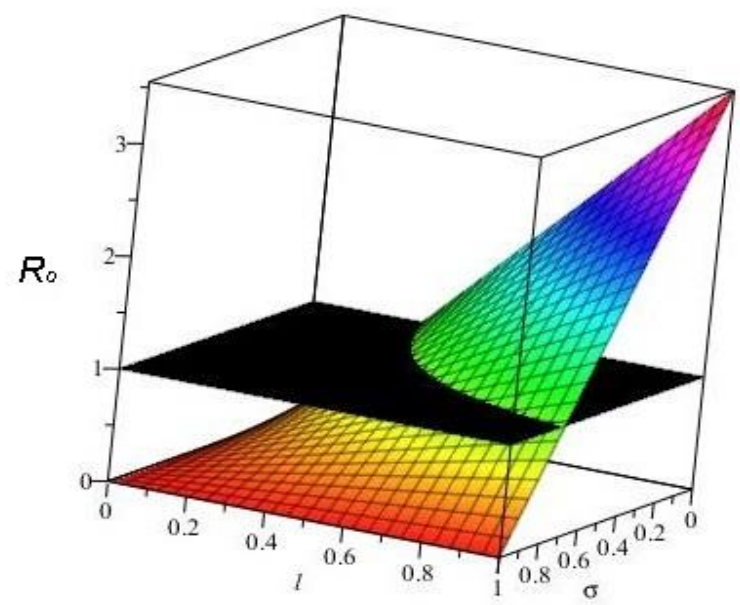

Gambar 5. Grafik untuk menentukan nilai parameter $l$ dan $\sigma$

Berdasarkan Gambar 5, dipilih nilai $l=0,2$ dan $\sigma=0,5$ sehingga akan menghasilkan $\mathfrak{R}_{0}=$ $0,3596081754\left(\Re_{0}<1\right)$. Kemudian dipilih juga nilai $l=0,5$ dan $\sigma=0,15$ sehingga akan menghasilkan $\mathfrak{R}_{0}=1,513539269\left(\mathfrak{R}_{0}>1\right)$. Didapat nilai sensitivitas pada model POV ketika $\mathfrak{R}_{0}<1$ dan $\Re_{0}>1$ yang disajikan pada Tabel 3 .

Berdasarkan Tabel 3, terlihat bahwa parameter proporsi individu isolasi yang berpotensi menginfeksi individu rentan $(l)$ mempunyai pengaruh positif terhadap penyebaran penyakit $S A R S$ ketika $\Re_{0}<1$ dan $\Re_{0}>1$. Ini berarti, jika parameter tersebut semakin besar maka banyaknya kasus SARS di populasi tersebut semakin banyak, dan sebaliknya. Sementara itu ketika $\mathfrak{R}_{0}<1$, parameter proporsi individu rentan yang berhasil divaksin sebelum terjadi wabah SARS dalam suatu populasi $(\sigma)$ memberikan pengaruh negatif terbesar terhadap penyebaran penyakit $S A R S$, dan ketika $\mathfrak{R}_{0}>1$ parameter laju pemulihan dari individu isolasi $\left(\gamma_{2}\right)$ yang memberikan pengaruh negatif terbesar terhadap penyebaran penyakit SARS. Ini berarti, semakin besar nilai 
parameter tersebut menyebabkan banyaknya kasus SARS semakin sedikit. Sedangkan untuk parameter laju pemulihan dari individu terinfeksi $\left(\gamma_{1}\right)$, memberikan pengaruh yang sangat kecil terhadap penyebaran penyakit $S A R S$ ketika $\mathfrak{R}_{0}<1$ dan $\mathfrak{R}_{0}>1$.

Tabel 3. Hasil analisis sensitivitas dari setiap parameter ketika $\mathfrak{R}_{0}<1$ dan $\mathfrak{R}_{0}>1$

\begin{tabular}{cll}
\hline $\begin{array}{c}\text { Sensitivitas dari } \\
\text { setiap parameter }\end{array}$ & \multicolumn{1}{c}{ Nilai sensitivitas } & \multicolumn{1}{c}{$\mathfrak{R}_{\mathbf{0}}>1$} \\
\cline { 2 - 3 } $\boldsymbol{\mathfrak { R }}_{\mathbf{0}}<1$ & $-0,1764705882$ \\
$S_{\sigma}$ & -1.000000000 & 0,9934830559 \\
$S_{l}$ & 0,9838653623 & $-0,6000562048$ \\
$S_{\gamma_{2}}$ & $-0,5942471915$ & $-0,3950899988$ \\
$S_{\delta}$ & $-0,3922681777$ & $-0,1403234568$ \\
$S_{\rho}$ & $-0,5165155406$ & $-0,003598037353$ \\
$S_{\theta}$ & $-0,01324398823$ & $-0,002754816532$ \\
$S_{\alpha}$ & $-0,01014018314$ & $-0,002098979957$ \\
$S_{\gamma_{1}}$ & $-0,003344447921$ & \\
\hline
\end{tabular}

Nilai parameter $l, \sigma$, dan $\gamma_{1}$ ketika $\Re_{0}<1$ akan dilihat kenaikannya sebanyak $10 \%, 50 \%$, dan $100 \%$ untuk menunjukkan bahwa hasil dari Tabel 3 sudah tepat. Hal tersebut dapat dilihat pada grafik berikut :
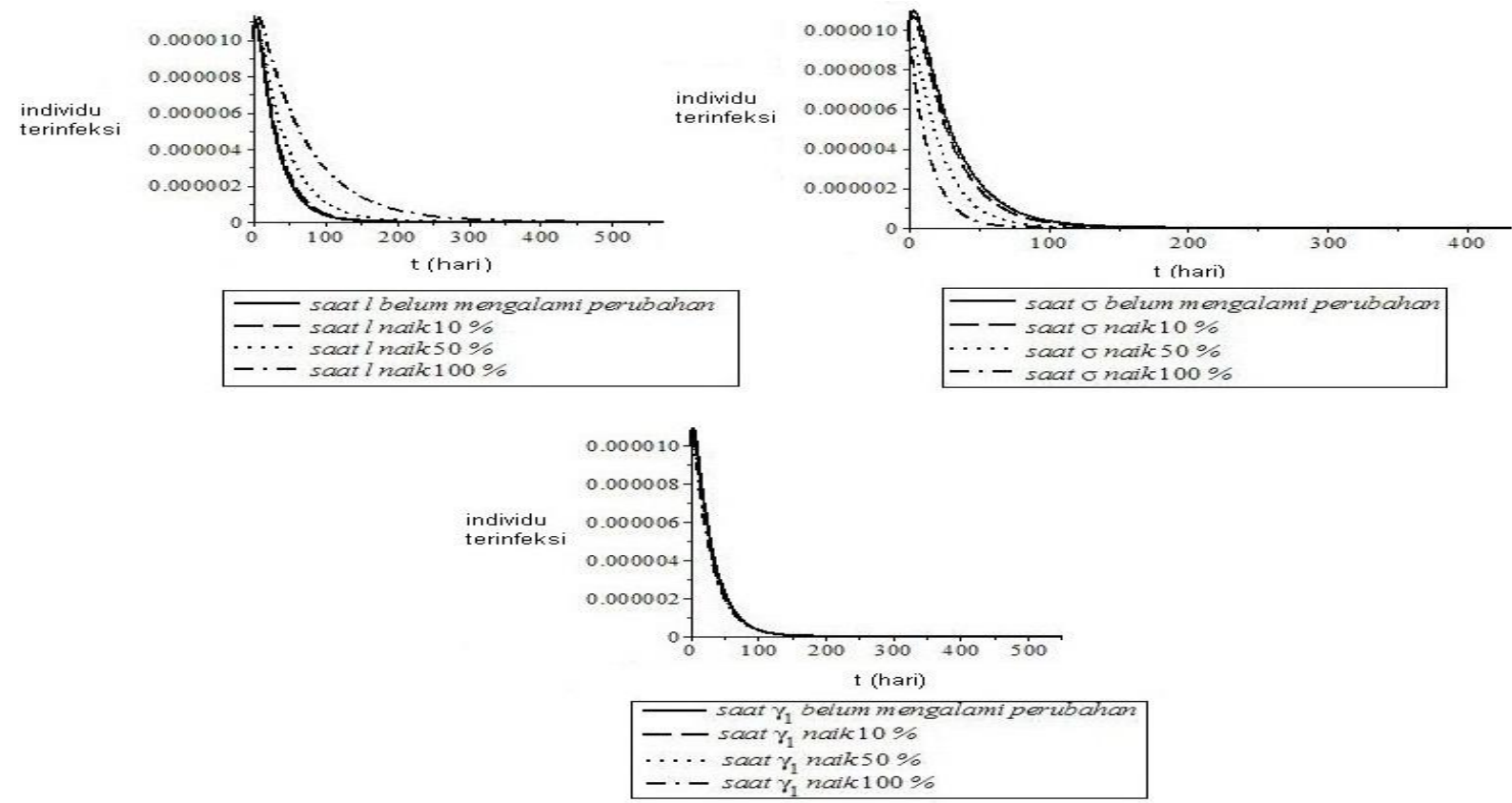

Gambar 6. Proporsi individu yang terinfeksi $S A R S$ ketika $\mathfrak{R}_{0}<1$ dengan perubahan pada parameter $l, \sigma$, dan $\gamma_{1}$ 
Berdasarkan Gambar 6, terlihat bahwa ketika parameter $\sigma$ naik 10\%, 50\%, dan $100 \%$ selalu terjadi penurunan pada proporsi individu yang terinfeksi penyakit $S A R S$. Saat awal $\sigma=0,5$, keadaan bebas penyakit terjadi sekitar $t=176$. Jika $\sigma$ naik $10 \%$, maka kejadian bebas penyakit akan lebih cepat terjadi yaitu sekitar $t=155$. Begitu pula jika $\sigma$ naik $50 \%$, kejadian bebas penyakit akan lebih cepat terjadi yaitu sekitar $t=127$. Kemudian ketika $\sigma$ naik $100 \%$, kejadian bebas penyakit lebih cepat terjadi dibandingkan dengan $\sigma$ awal dan ketika $\sigma$ naik 10\% maupun 50\% yaitu sekitar $t=87$. Hal ini sesuai dengan $S_{\sigma}$ yang bernilai negatif terbesar pada Tabel 3.

Ketika $l$ naik $10 \%$, 50\%, dan $100 \%$ selalu terjadi kenaikan pada proporsi individu yang terinfeksi penyakit $S A R S$. Saat awal $l=0,5$, keadaan bebas penyakit terjadi sekitar $t=170$. Jika $l$ naik $10 \%$, maka kejadian bebas penyakit akan lebih lama terjadi yaitu sekitar $t=18$. Begitu pula jika $l$ naik 50\%, kejadian bebas penyakit akan lebih lama terjadi yaitu sekitar $t=252$. Kemudian ketika $l$ naik $100 \%$, kejadian bebas penyakit lebih lama terjadi dibandingkan dengan $l$ awal dan ketika $l$ naik $10 \%$ maupun $50 \%$ yaitu sekitar $t=398$. Hal ini sesuai dengan $S_{l}$ yang bernilai positif pada Tabel 3 .

Ketika $\gamma_{1}$ naik $10 \%, 50 \%$, dan $100 \%$ tidak terjadi penurunan yang signifikan pada proporsi individu yang terinfeksi penyakit $S A R S$. Keadaan bebas penyakit akan terjadi sekitar $t=165$. Hal ini sesuai dengan $S_{\gamma_{1}}$ yang bernilai negatif terkecil. Jadi, dugaan bahwa parameter $l$ dan $\sigma$ dapat mengontrol penyebaran penyakit $S A R S$ paling signifikan dibandingkan parameter lainnya ketika $\mathfrak{R}_{0}<1$ adalah benar. Perhatikan juga potret fase model $P O V$ ketika $\mathfrak{R}_{0}<1$ berikut:
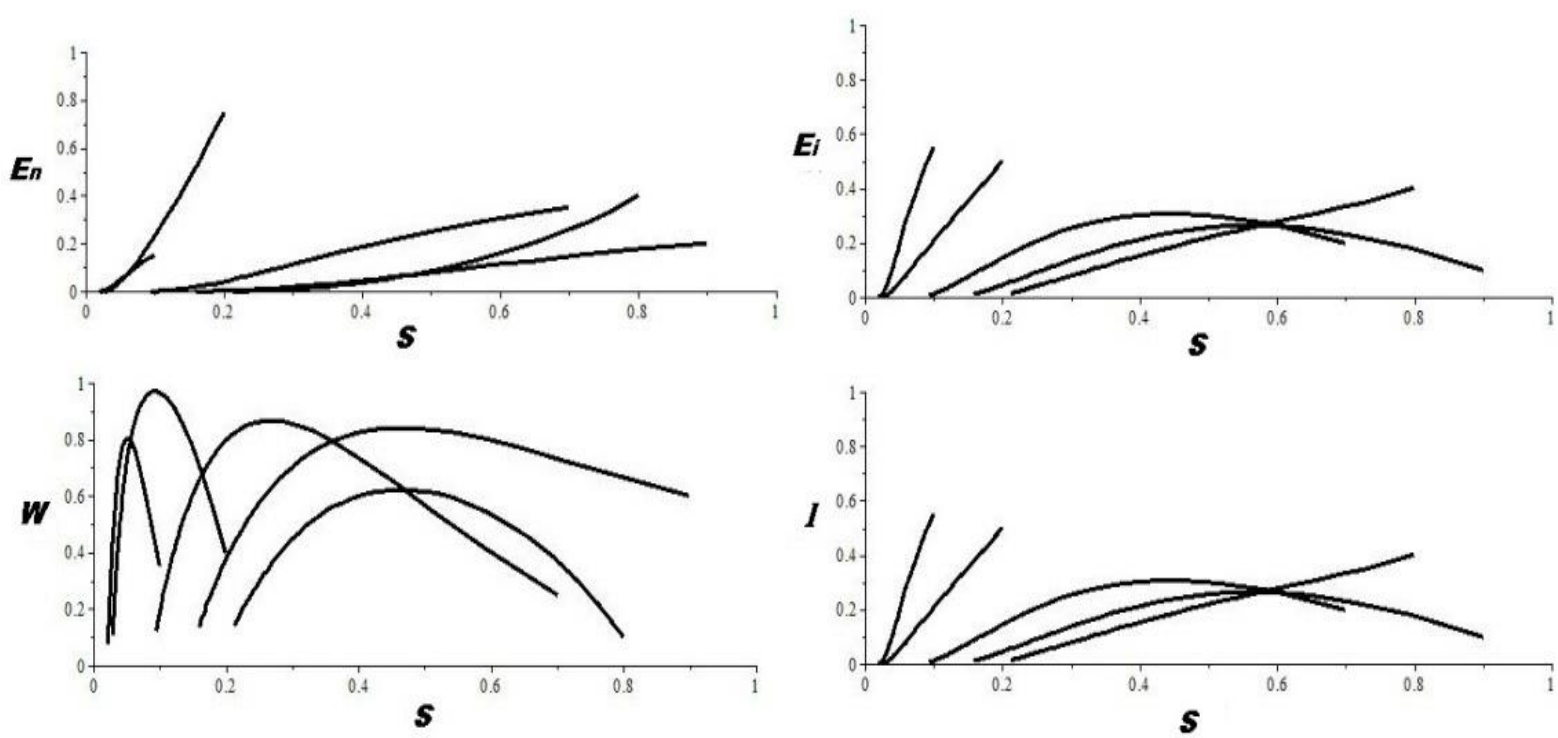

Gambar 7. Potret fase model $P O V$ ketika $\Re_{0}<1$

Berdasarkan Gambar 7, terlihat bahwa untuk sembarang nilai awal proporsi individu terinfeksi akan selalu menuju nol berapapun jumlah individu rentan dalam suatu populasi. Hal 
tersebut menunjukkan bahwa titik kesetimbangan bebas penyakit model $P O V$ stabil. Sehingga, hasil analisis sensitivitas pada model $P O V$ ketika $\mathfrak{R}_{0}<1$ benar bebas penyakit.

Nilai parameter $l, \gamma_{1}$, dan $\gamma_{2}$ ketika $\Re_{0}>1$ akan dilihat kenaikannya sebanyak $10 \%, 50 \%$, dan $100 \%$ untuk menunjukkan bahwa hasil dari Tabel 3 sudah tepat. Hal tersebut dapat dilihat pada grafik berikut :
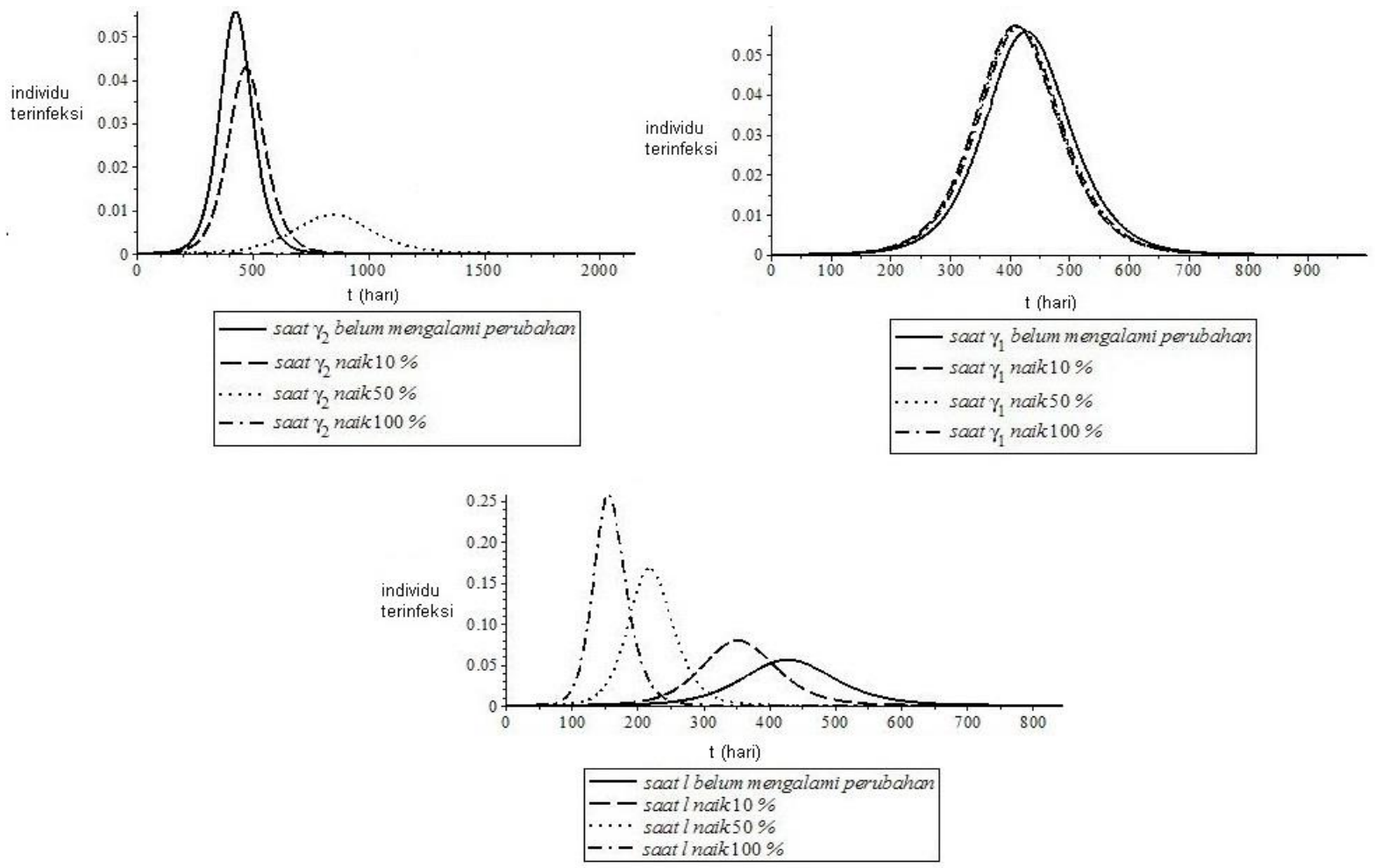

Gambar 8. Proporsi individu yang terinfeksi $S A R S$ ketika $\mathfrak{R}_{0}>1$ dengan perubahan pada parameter $l, \gamma_{1}$, dan $\gamma_{2}$

Berdasarkan Gambar 8, terlihat bahwa ketika parameter $\gamma_{2}$ naik 10\%, 50\%, dan $100 \%$ selalu terjadi penurunan pada proporsi individu yang terinfeksi penyakit SARS. Saat awal $\gamma_{2}=0,0425$, keadaan munculnya penyakit terjadi sekitar $t=423$. Jika $\gamma_{2}$ naik $10 \%$, maka kejadian munculnya penyakit akan lebih lama terjadi yaitu sekitar $t=427$. Begitu pula jika $\gamma_{2}$ naik 50\%, kejadian munculnya penyakit akan lebih lama terjadi yaitu sekitar $t=842$. Kemudian ketika $\gamma_{2}$ naik $100 \%$, kejadian munculnya penyakit lebih lama terjadi dibandingkan dengan $\gamma_{2}$ awal dan ketika $\gamma_{2}$ naik $10 \%$ maupun $50 \%$. Ketika $\gamma_{2}$ naik $100 \%$ penyakit sudah hamper hilang. Hal ini sesuai dengan $S_{\gamma_{2}}$ yang bernilai negatif terbesar pada Tabel 3.

Ketika $l$ naik $10 \%, 50 \%$, dan $100 \%$ selalu terjadi kenaikan pada proporsi individu yang terinfeksi penyakit $S A R S$. Saat awal $l=0,5$, keadaan munculnya penyakit terjadi sekitar $t=426$. 
Jika $l$ naik $10 \%$, maka kejadian munculnya penyakit akan lebih cepat terjadi yaitu sekitar $t=352$. Begitu pula jika $l$ naik 50\%, kejadian munculnya penyakit akan lebih cepat terjadi yaitu sekitar $t=217$. Kemudian ketika $l$ naik $100 \%$, kejadian munculnya penyakit lebih cepat terjadi dibandingkan dengan $l$ awal dan ketika $l$ naik $10 \%$ maupun $50 \%$ yaitu sekitar $t=157$. Hal ini sesuai dengan $S_{l}$ yang bernilai positif pada Tabel 3 .

Ketika $\gamma_{1}$ naik $10 \%, 50 \%$, dan $100 \%$ tidak terjadi penurunan yang signifikan pada proporsi individu yang terinfeksi penyakit $S A R S$. Keadaan munculnya penyakit akan terjadi sekitar $t=201$. Hal ini sesuai dengan $S_{\gamma_{1}}$ yang bernilai negatif terkecil. Jadi, dugaan bahwa parameter $l$ dan $\sigma$ dapat mengontrol penyebaran penyakit $S A R S$ paling signifikan dibandingkan parameter lainnya ketika $\mathfrak{R}_{0}>1$ salah. Ternyata, parameter $l$ dan parameter $\gamma_{2}$ yang paling berpengaruh dalam mengontrol penyebaran penyakit $S A R S$. Perhatikan juga potret fase model $P O V$ ketika $\mathfrak{R}_{0}>1$ berikut:
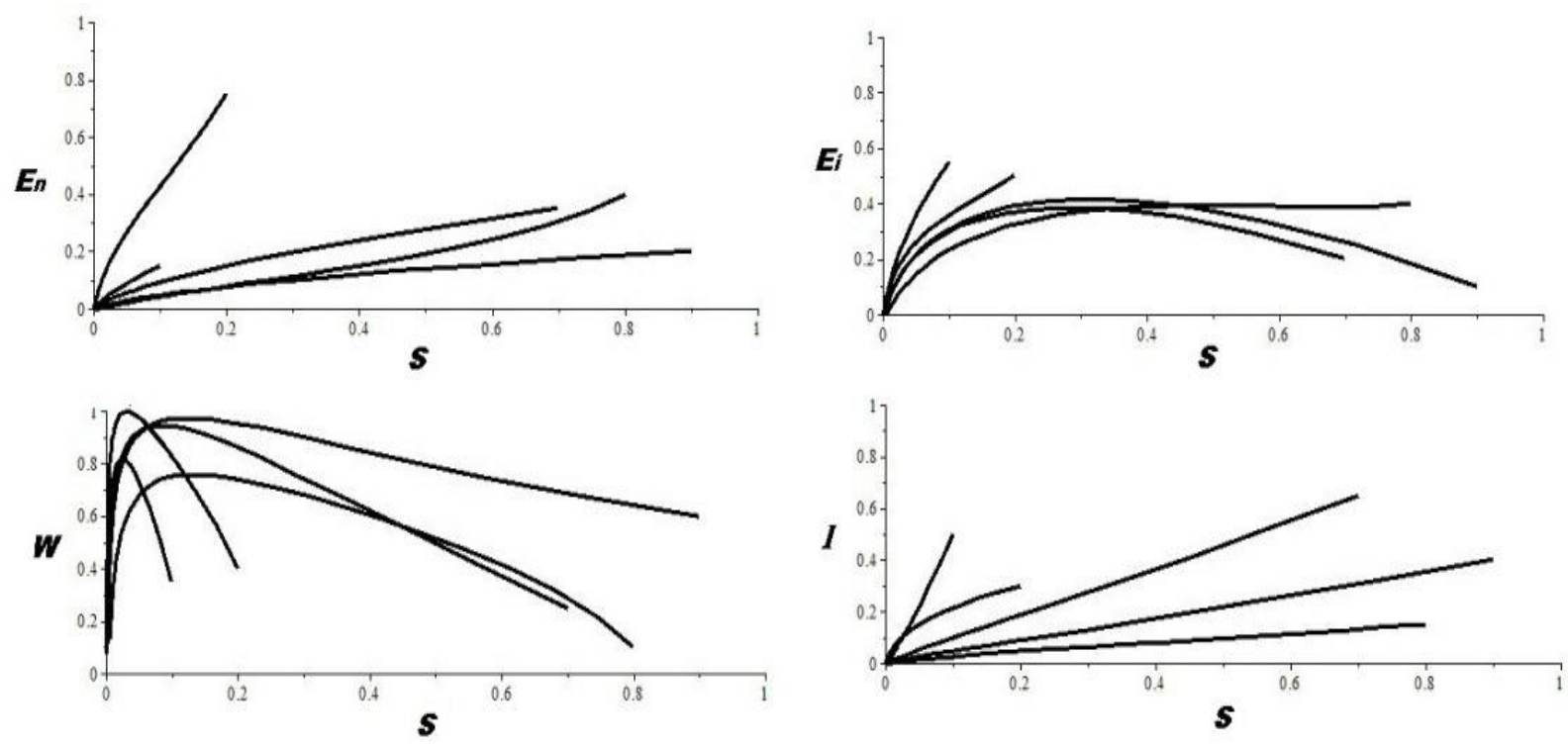

Gambar 9. Potret fase model $P O V$ ketika $\mathfrak{R}_{0}>1$

Berdasarkan Gambar 9, terlihat bahwa untuk sembarang nilai awal proporsi individu terinfeksi akan selalu menuju nol berapapun jumlah individu rentan dalam suatu populasi. Hal tersebut menunjukkan bahwa titik kesetimbangan bebas penyakit model POV stabil. Sehingga, hasil analisis sensitivitas pada model $P O V$ ketika $\mathfrak{R}_{0}>1$ benar bebas penyakit meskipun penyakit $S A R S$ sempat muncul. 


\section{Simpulan}

Berdasarkan simulasi Monte Carlo pada model POV, dapat disimpulkan bahwa parameter proporsi individu isolasi yang berpotensi menginfeksi individu rentan yang berdistribusi $\operatorname{Beta}(\mathrm{a}=1, \mathrm{~b}=2)$ memiliki pengaruh paling besar dengan $\mathfrak{R}_{0}<1$ sebesar $83 \%$ dan rata-rata $\mathfrak{R}_{0}$ memiliki nilai yang paling kecil yaitu sebesar 0,58 . Begitu pula untuk model $D O V$, dapat disimpulkan bahwa parameter proporsi individu isolasi yang berpotensi menginfeksi individu rentan yang berdistribusi $\operatorname{Beta}(\mathrm{a}=1, \mathrm{~b}=2)$ memiliki pengaruh paling besar dengan $\mathfrak{R}_{0}<1$ sebesar $64,8 \%$ dan rata-rata $\mathfrak{R}_{0}$ memiliki nilai yang paling kecil yaitu sebesar 1,18.

Analisis sensitivitas pada bilangan reproduksi dasar model $P O V$ ketika $\Re_{0}<1$ dan ketika $\mathfrak{R}_{0}>1$ menunjukkan bahwa parameter proporsi individu isolasi yang berpotensi menginfeksi individu rentan mempunyai pengaruh positif terhadap penyebaran penyakit SARS. Sementara itu, ketika $\mathfrak{R}_{0}<1$ parameter proporsi individu rentan yang berhasil divaksin sebelum terjadi wabah $S A R S$ dalam suatu populasi memberikan pengaruh negatif terbesar terhadap penyebaran penyakit $S A R S$. Ketika $\mathfrak{R}_{0}>1$ parameter laju pemulihan dari individu isolasi memberikan pengaruh negatif terbesar terhadap penyebaran penyakit SARS.

\section{Daftar Pustaka}

[1] P. L. Delamater, E. J. Street, T. F. Leslie, Y. T. Yang, dan K. H. Jacobsen, "Complexity of the Basic Reproduction Number ( $\left.\mathrm{R}_{0}\right)^{\prime}$, Emerging Infectious Diseases, vol. 25, 2019.

[2] P. Efelin, B. Yong, dan L. Owen, "Model Penyebaran Penyakit SARS dengan Pengaruh Vaksinasi", Prosiding Seminar Nasional Matematika Universitas Katolik Parahyangan, vol. 11, pp. 77-85, 2016.

[3] J. Gjorgjieva, K. Smith, G. Chowell, F. Sanchez, J. Snyder, dan C. Castillo-Chaves, "The Role of Vaccination in the Control of SARS", Mathematical Biosciences and Engineering, vol. 2, 2005.

[4] Jing Li, D. Blakeley, dan R. J. Smith?, "The Failure of Ro", Computational and Mathematical Methods in Medicine, vol. 2011, 2011.

[5] Nurhayati, "Studi Perbandingan Metode Sampling Antara Simple Random dengan Stratified Random", Jurnal Basis Data, ICT Research Center UNAS, vol.3, no.1, 2008.

[6] Yicang Zhou dan Zhien Ma, "A Discrete Epidemic Model for SARS Transmission and Control in China", Mathematical and Computer Modelling, vol. 40, pp. 1491-1506, 2003.

[7] Juan Zhang, Jie Lou, Zhien Ma, dan Jianhong Wu, "A Compartmental Model for The Analysis of SARS Transmission Patterns and Outbreak Control Measures in China", 
Applied Mathematics and Computation, vol. 162, pp. 909-924, 2004.

[8] G. Chowell, C. Castillo-Chavez, P. W. Fenimore, C. M. Kribs-Zaleta, L. Arriola, dan J. M. Hyman, "Model Parameters and Outbreak Control for SARS", Emerging Infectious Diseases, vol. 10, pp. 1258-1263, 2004.

[9] J. Y. Kodaira dan J. R. de Souza Passos, "The Basic Reproduction Number in SIR Models - A Probabilistic Approach", 9th Brazilian Conference on Dynamics, Control and Their Application, 2010.

[10] Wendi Wang dan Shigui Ruan, "Simulating the SARS outbreak in Beijing with limited data", Journal of Theoretical Biology, vol. 227, pp. 369-379, 2004.

[11] G. Chowell, F. Abdirizak, S. Lee, J. Lee, E. Jung, H. Nishiura, dan C. Viboud, "Transmission characteristics of MERS and SARS in the healthcare setting: a comparative study", BMC Medicine, vol 13:210, 2015.

[12] K. O. Okosun, M. Mukamuri, dan D. O. Makinde, "Global Stability Analysis and Control of Leptospirosis", Open Mathematics, vol. 14, pp. 567-585, 2016.

[13] H. S. Rodrigues, M. T. T. Monteiro, dan D. F. M. Torres, "Sensitivity Analysis in a Dengue Epidemiological Model", Conference Papers in Mathematics, vol. 2013, 2013.

[14] H. W. Berhe, O. D. Makinde, dan D. M. Theuri, "Parameter Estimation and Sensitivity Analysis of Dysentery Diarrhea Epidemic Model", Journal of Applied Mathematics, vol. 2019, 2019.

[15] P. v. d. Driessche, "Reproduction numbers of infectious disease models", Infectious Disease Modelling, vol. 2, pp. 288-303, 2017.

[16] Hyun Mo Yang, "The basic reproduction number obtained from Jacobian and next generation matrices - A case study of dengue transmission modelling", BioSystems, vol. 126, pp. 52-75, 2014.

[17] A. Khan, M. Hassan, dan M. Imran, "Estimating the basic reproduction number for singlestrain dengue fever epidemics", Infectious Diseases of Poverty, vol. 3:12, 2014.

[18] K. Sato, "Basic reproduction number of SEIRS model on regular lattice", Mathematical Biosciences and Engineering, vol. 16:6, pp. 6708-6727, 2019. 